\title{
Behind the Mask and Look Me in The Eye: Exploring the Relation of Self-Confidence With Conformity in Today's Teenagers
}

\section{Dewanti, H.L.}

English for Creative Industry, Faculty of Letters, Petra Christian University, Siwalankerto 121-131, Surabaya 60236, East Java, INDONESIA

Emails: m11414063@john.petra.ac.id

\begin{abstract}
Teenagers are particularly susceptible to conformity and apparently self-confidence plays a significant role in how teenagers make individual choices. Drawing on the relevance between the two, this creative project explores today's teenagers' manner on conformity and assesses how teenagers' self-confidence is related to their decision to conform or not to conform. To understand how self-confidence and conformity relate to each other deeper, I use Herbert Kelman's theory of the three processes of attitude change in conformity and Mastuti's theory of self-confidence on self-confidence. This creative project is two plays of 30 minute play which explores about the same issue but is seen from different angle of perspectives. Behind the Mask focuses on how a teenager who has lack of self-confidence conforms to her peer group while Look Me in the Eye focuses on how a teenager who has self-confidence conforms to her peer group. Showing different angle of perspectives help me conveying my purpose of writing the plays which is to help teenagers understand that conformity in daily life is inevitable and how their self-confidence plays an important role so that they will not get influenced by conformity easily. For the genre, the plays use realistic drama as the genre conventions suit the style of my plays which portrays a conflict that happens in teenagers' daily life in a realistic way.
\end{abstract}

Key words:

Conformity, self-confidence, teenagers

\section{INTRODUCTION}

The starting point of a theatrical production lies in the playwrights as their job is not only to create the material for the play but also to uncover truths that happens in the society and sculpt it through meaningful dialogue. Play itself is a medium which relies heavily on the dialogue. The action of the play does not occur through visual but within the language of dramatic action which describes feelings, emotion, and even to contrast types of the characters (BBC, n.d). This characteristic turns to be the strength of a play in term of encouraging the readers' creativity, and it becomes the reason why I choose this form. The readers will actively engage their imagination while reading a play and this thing can help them experiment with language in term of tone of voice or even body language. In addition, the limitation of a play can create a believable situation to the readers.

To emphasize the believable situation, I use realistic drama as the genre of my creative work. Realistic drama, which comes from realism movement, describes any play that depicts reality as it is (Jones, n.d). It involves plausible events and problems that could have occurred to people in a believable setting. Choosing realistic drama as my genre helps me discuss the issue that I want to talk about which is the manner of conformity in teenagers' life. According to David Myers, the Professor of Psychology at Hope College in United States, conformity is "the change of behavior or belief as a result of real or imagined group pressure" (Myers, 2012). In other words, an individual changes his behavior to adjust themselves according to the existing social norm.

A conformity can happen because of the social pressure and an individual wants to be liked in his group of society. Hendriati Agustiani, a lecturer in Padjajaran University in Developmental Psychology, explained in her book that one of the society groups that is easily affected by this issue is teenagers, especially within the age 13-17 years old (Agustiani, 2006). During adolescent, the 
social needs of individuals increase. They will try to expand their social environment outside their family, such as peers (ibid.). Teenagers perform conformity at this kind of situation with the intention of getting acceptance from their peers.

Conformity in teenagers does not just happen. There are many things that influence teenagers to conform and self-confidence is one of the influences. One of educational psychologists in Indonesia, Agus Dariyo, explained self-confidence in his book as an attitude or feelings of confidence on oneself ability so that the person is certain with his actions, can do the things that he likes freely and be responsible for his actions, and can recognize his strengths and weaknesses (Lauster as cited in Dariyo, 2004). By having self-confidence, or the belief in one's ability, an individual will not be easily affected by people and can act accordance to his will and be responsible of it. If an individual performs conformity and acts in accordance to the group rather than on his will alone, then it can be assumed that the individual may lack of self-confidence. Sears, Freedman, and Peplau as cited in Baron and Byrne (2005), also strengthen this thing with their statement that self-confidence can affect the level of conformity. The lack of confidence in the individuals can lead to a higher level of conformity.

In my creative work, I focus on how high school students struggle to fit in or conform to their peer group. During the adolescent years, peer groups become extremely important as teenagers experience more closeness in these friendships and more gratifying relationships with their peers (Oswalt, 2010). Baron and Byrne also stated in their book that there is nothing wrong in wanting to fit in because everyone needs to belong or feel connected to his group (Baron \& Byrne, 2005). However, it may become a concern if teenagers downplay or even lose their self-identity due to their attempt to "fit in" in a peer group. Nevertheless, I believe that self-confidence plays a part for teenagers in drawing boundaries between conformity and losing their self-identity. The aim of this creative work is to explore the relation between the two without taking sides whether it is okay or not okay to conform. To deliver the idea, I create two plays of 30 minutes play. Both of the plays discuss about the same issue but I use different point of view to explore the issue in depth. By so doing, I can show a contrast between how a teenager who has self-confidence compare to a teenager who has lack of self-confidence deal with conformity.

Both of the plays that I make discuss a female high school student who is trying to "fit in" in her peer group. However, the first play focuses on how a teenager who has lack of self-confidence conforms to her peer group. Meanwhile, the second play focuses on how a teenager who has selfconfidence conforms to her peer group. In the first play, the main character, Kiki, seeks for her peer group acceptance that she bothers to hide her true identity, lie to her friends, and even betray her own family in order to be accepted. She is doing all of those things because she thinks it will help her to get what she wants, which is a recommendation to get into her dream university. Meanwhile in the second play, the main character, Felicia, is getting pressured by her surroundings expectations. Her surroundings expect her to follow her father's path which is in education while she actually wants to be in different path which is in film industry. Her father even uses his power to force her to conform to the role but she cannot agree with his father's action. That is why, Felicia decides to confront her father. I want to use them to show how teenagers with different influence struggle and cope with conformity. As the story goes, the readers will understand how conformity in today's teenagers and self-confidence relate to each other.

It cannot be denied that conformity is inevitable and is needed in the society to prevent chaos. Even in the context of conforming to a group of society, I believe everyone has tried to fit in and there is nothing wrong with it because it is a human nature to have the need to belong in a group. However, I want to consider what triggers individuals to conform or not to conform and whether self-confidence plays a role to make individuals conform or not to conform to a group of society.

Through this creative work, I want to show that peers' rejection may lead teenagers to conformity while teenagers' belief in themselves may lower teenagers' possibility to conform. I also want to show that teenagers who have lack of self-confidence have a difficulty to voice their opinion but just follow the crowd while teenagers who have self-confidence know what they want and fight for it.

In creating this work, I applied two theories to help me have deeper understanding in conformity and self-confidence, and how it relates to each other. The first theory that I use is the three processes of attitude change by Herbert Kelman. He identified that there are three processes of 
attitude change or conformity: compliance, identification, and internalization. Compliance occurs when an individual conforms not because he believes in the norm, but he hopes to achieve a favorable reaction from the group or avoid certain punishment. The change of behavior when an individual complies only happens at the outside while privately does not believe the norm, and it may stop when there are no group pressures to conform (Kelman, 1958). Identification occurs when an individual conforms to the expectation of social role. It is similar to compliance as there does not have to be a change in private opinion. (ibid). Internalization occurs when an individual adopts a behavior because it is compatible with his value (ibid). It is more likely established by people or groups that are influential to the individual. In this level, an individual publicly changes their behavior to fit in with the group, while also agreeing with them privately.

The second theory that I use is self-confidence by Mastuti. As stated by Mastuti (2008), selfconfidence is individuals' attitude in evaluating themselves and the surroundings so that they believe in their ability and to be able to do something in accordance with their abilities. She also explained several characteristics of individuals who have self-confidence and here are some of them:

1. Believe in their own competencies and abilities so that they do not need acceptance from others.

2. Do not perform conformity with the intention to be accepted in a certain group.

3. Have no fear of getting rejection from others and have the courage to be themselves.

4. See success and failure from their own effort and do not give up easily to circumstances, also do not depend and expect help from others.

Besides the two theories above, I also use two methods, which are the primary and the secondary research method. I obtained my secondary research result by reading journals and articles I found on the internet, and also books, written by the experts regarding teenagers and conformity. I also read articles and books about self-confidence and adolescent development to get a better understanding of how self-confidence and conformity in teenagers relate to each other. To support the secondary research, I also did a primary research while working on this project, which is by observing some high school students. I tried to pay attention to their behavior when they are around their peer group and how similar their behavior is. I also tried to see how they act when they are around their family in order to know their change of behavior. By doing this, it can help me creating realistic characters and conflicts for my creative work.

\section{OUTLINE OF THE CREATIVE WORK}

\subsection{Theme}

The subject matter of my work is conformity and the general theme of my plays is how self-confidence has a significant role in influencing teenagers to make individual choices whether or not to conform. As I have mentioned above, I create two plays to make a contrast between a teenager who has and has not self-confidence. As the story goes, the readers will understand how conformity and self-confidence relate to each other.

\subsection{Plot \\ 2.2.1 Behind the Mask}

The play talks about Kiki, a sophomore in high school, who wants to go to Wijaya University to study film. Unfortunately, her family cannot support her due to financial issue and want her to help with family catering business. Not giving up on her dream, she tries to join a short movie competition that is held by her school and Wijaya University. By winning this competition, she can get a recommendation to get into Film major in Wijaya University. She joins this competition with Felicia, and Gaby. She thinks that Felicia can help her win the competition since Felicia is good with camera and own photography gear. Plus, she is the daughter of the school principal.

Kiki is currently at the film club room. Felicia, Gaby, and her are going to discuss about their short movie that they are going to submit next week. While waiting for Felicia and Gaby to come, Kiki is editing the short movie. Later, she gets a call from her older sister, Dhella, asking when she will come home because she needs her help at home. Kiki just answers the call half-heartedly and hangs it up when Felicia and Gaby enter the room. During their discussion about their short movie, Kiki starts to get annoyed because Felicia keeps criticizing her editing without even helping her and 
Gaby keeps busy with her phone. However, she cannot do anything because she needs their, especially Felicia, help. That is why, Kiki keeps agreeing on whatever Felicia and Gaby say or ask.

By the time when things go as Kiki wants, Dhella starts to call her repeatedly but Kiki deliberately neglects it. Felicia and Gaby misunderstand it as Kiki's boyfriend who is calling so they excuse themselves to go to the toilet. After they leave the room, Kiki surprises to find Dhella comes into her school to pick her up. Unfortunately, Felicia and Gaby come back when they are in the middle of arguing. Felicia asks who Dhella is but Kiki hides the truth about Dhella which makes Dhella annoyed. As their conversation goes, Dhella finds out that Kiki makes up stories about her family. Even though Kiki tries her best to convince Felicia and Gaby that she is not lying, she fails in the end. Felicia and Gaby disappoint on Kiki then decide to withdraw themselves from the competition and leave Kiki. Kiki feels that Dhella fails her plan and blames her on everything. On the other hand, Dhella does not feel that she is doing anything wrong since she just says the truth. Kiki's stubbornness irritates Dhella and she, just like Felicia and Gaby, leaves Kiki alone. Kiki, still with her stubbornness, back to her seat and feels the bitter result of her choice.

\subsubsection{Look Me in the Eye}

This play is seen from Felicia's point of view and it happens a year after the incident in the first script. It talks about how people at school, including her father, see her as a deviant because she does not want to be in the same path as her father. The school, with Wijaya University, currently offers a scholarship to get into film major and it is only for one student. Felicia, who wants to get into film major, also tries to apply for the scholarship. The play begins with Felicia goes to the film club room to find Pak Hadi, the teacher in charge for the scholarship program. She wants to ask for Pak Hadi's advice but it turns out that Pak Hadi questions her desire to get into film major. Pak Hadi thinks that it is regrettable for Felicia to get into film major because he can see that Felicia has the potency to become a teacher. This is also supported by the fact that Felicia's parents are teachers and her family runs a private course. However, Felicia believes that those things do not define what she wants to do.

Not long after, Kiki enters the room. She brings her scholarship document and gives it to Pak Hadi. She asks Pak Hadi to check the document again before he takes and submit the document. Felicia then surprises when she finds Kiki has a recommendation letter. Felicia asks for Pak Hadi's help to get her a recommendation letter too but Pak Hadi gives her a flyer of a scholarship to get into education major instead. After Pak Hadi leaves the room, Kiki expresses her disagreement of Felicia applying for the same scholarship as her. Kiki also starts to provoke Felicia when she receives a message from her friend saying that Felicia got the scholarship to get into education major and she knew it from the school principal. While Felicia still cannot accept the news, Gaby enters the room and congratulates her. Lukily, Gaby understands her situation and wants to help her to decline the scholarships. Gaby tries to offers some idea but Felicia disagrees with that.. Felicia then decides to confront her father and settle things herself.

In the second scene, Felicia goes to her father's office to ask him to cancel the scholarship. Felicia's father insists that it is for her future but Felicia disagrees with it. For Felicia, her father is being inconsiderate because he decides things on hiw own without asking for Felicia's opinion.

While her father goes out of the room, she tries to fake her father's signature and swaps the document. However, her father finds it out. Still cannot accept it, Felicia rips the document but her father says it is useless because he can ask his friend who works in Wijaya University to send him the new one. Once her father goes out of the room to call his friend, Felicia grabs the telephone on the desk to call the university to report what her father did. Because of this, her father's friend who helps him is called by the superior. Felicia then tries to convince her father again that she does not need her father to get her the scholarship but to believe in her. In the end, her father grants Felicia wish to cancel the scholarship and let Felicia to do what she wants.

\subsection{Characters}

\section{The characters below will appear in the first and second script}

$$
\text { - Kiki }
$$

Age: 16 years old

Coming from a less fortunate family and having experiences of being bullied by her peers, Kiki grows as a teenager who has lack of self-confidence. Kiki is strong willed and 
perfectionist. This often makes her feel insecure about everything that she does. She often hides her weaknesses and sometimes lies to hide it.

- Felicia

Age: 16 years old

Felicia is the daughter of the school principal of the school she goes which is Harapan Senior High School. She is friendly and sociable. It is easy for her to get along with people which becomes the reason on why she has many friends. She is the kind of friend who will stand for their friends and help those who need her. However, it is hard for her to forgive someone who breaks her trust. She knows what she wants and fights for it. However, she can be impulsive sometimes. She enjoys filmmaking and wants to work in the film industry in the future.

- Gaby

Age: 16 years old

Gaby is Felicia's close friend since junior high school. She is an outgoing person and really into social media. She likes to share on her social media and manages it well. She is talkative and full of curiosity. With her friends, she believes that her friends and her should share about everything and should not keep secrets.

\section{The character below will appear in the first script only}

- Dhella

Age: 23 years old

Kiki's older sister. She is straightforward, strict, hard worker. She did not go to college and decided to work in the family catering business because she wants to help her mother. Though her mother still can work with the business, she often gets sick.

\section{The character below will appear in the second script only \\ - Pak Hadi}

Age: 55 years old

$\mathrm{He}$ is the art teacher as well as the teacher in charge for film club in Kiki's school. Currently, he is chosen as the teacher in charge for the cooperation program between the school and the film major in Wijaya Univeristy. He can talk casually with the students. He likes to talk about his past experiences. He is discipline and quite conservative.

\section{- Pak Ronny}

Age: 45 years old

Felicia's father as well as the school principal in Harapan Senior High School. He wants the best for Felicia and will do anything for it. He is assertive and quite selfish. Once he plans for something, he wants things to go as he wants.

\subsection{Conflict}

\subsubsection{Behind the Mask}

The main conflict of this play is between Kiki and Dhella. At first, Kiki is still working on her plan to conform to Felicia and Gaby. The conflict starts to rise when Dhella suddenly comes to her school to pick her up. In front of Felicia and Gaby, Kiki keeps hiding the truth about herself because she does not want them to find out her hidden agenda. The conflict reaches its climax when Kiki does not acknowledge her own mother which makes Dhella mad and blurt out the truth. Kiki is in the middle in convincing Felicia and Gaby to keep believing in her and making excuses for Dhella's claimed.

\subsubsection{Look Me in the Eye}

The main conflict of this play is between Felicia and her father. Felicia wants to get into film major and work in film industry but her father against it. Her father, as well as her surroundings, expect her to get into education major and to be a teacher because she comes from a family which has education background. The conflict rises when she finds out that her father uses her power as the school principal to make her gent into education major. The conflict reaches its climax when she confronts her own father and ask him to cancel her scholarship. Felicia refuses to 
follow her father and her surroundings expectation and wants to fight for what she wants with her own effort.

\section{CONCLUSION}

\subsection{Lessons Learned}

I have encountered many challenges during my process finishing this project. It even begins from the time I choose the topic of my creative work. I have always been having concern towards conformity in teenagers and wondering what makes them decide to conform or not to conform. I thought it must be interesting to explore about this and that is why I decided to use conformity as my topic. However, as I working on this project, I realized that conformity is a challenging topic. In a way, it is a "peace" topic - meaning that I have to find a strong reason on why it becomes a concern that is worth talking about. There were times when I thought about changing my topic but then I found myself get attached to this topic already. From this experience, I learned to keep a commitment that I have made and work on it wholeheartedly. This realization made me work hard in researching everything about conformity. I learned about the causes and effects of conformity which made me find out that people are actually doing different kinds of conformity as there are many types of it depending on the circumstances. I learned about teenagers development and their characteristics, and that made me realize that teenagers are prone to conformity, so it is understandable that they become one of the groups of society that get influenced by conformity easily. I also learned about the role and importance of having self-confidence as teenagers, which apparently will continue to affect them as they grow up.

The most difficult challenge that I have to face while writing the plays is crafting the dialogue. Though I have gotten the chance to get involved in several theatre productions, writing a play is a new experience for me. It is not as easy as just writing conversations between the characters. Since the story and the conflict of a play lay in the dialogue, I have to make sure that each dialogue is meaningful. Every time I made a dialogue, I had to ask myself some questions like "why the character says this?", "is it necessary?", or "will this kind of character say this dialogue?" Even though it took time, answering those questions helped me not to make dialogue at random. I realize that I am still lacking but I can feel the improvements in my writing. To create meaningful dialogues in a play, I have to make sure that I have deep understanding not only in my story plot, but also my characters.

Another important thing that I learned during the process is that, as a playwright, I should have placed myself as a reader as well. I still remember the time when I was struck by these questions: "Will the readers understand this play?", "Will the readers enjoy this play?" I was busy writing about what I want that I forgot about my readers. Moreover, my target readers are teenagers. It is no longer a secret that teenagers nowadays have shorter attention span. They will not pay attention if it is not interesting for them. Considering this thing, I realized that I had to create something that will be able to catch their interest and to make them feel relatable. I finally came up with decision to put todays' trends in the plays such as making use of social media to build the conflict and also using slang words that currently popular among teenagers nowadays.

\subsection{Future Plan}

I realize that there are so many things that I need to learn and improve as a playwright. I am planning to revise these plays so that it will worth to be performed as it is one goal that I want to accomplish. I do not want this work to be my last play so I plan to write another play in the future. I have interest in creating a compilation book of short plays. I might be focusing my work for teenagers because I believe that play can be a great media for them to either learn language or raise social awareness. I also hope that by creating relatable and feasible play can make them put interest in play or even produce one.

\subsection{Suggestions / Recommendations}

Working on this project give me the chance to explore about the manner of conformity in teenagers in depth. Conformity is indeed inevitable for everyone but teenagers are at higher risk to take conformity too far because they are in a critical stage of rapid development and are highly selfaware. In my work, I use female high schoolers as my main characters because I found out that females are more prone to conformity due to belief that females are more concerned than males with social aspects of interactions and others' feelings. I put my focus to females that I did not have the chance to explore male attitude towards conformity. I found that males have different levels of self- 
concern. On average, males are more concerned about appearing to have high status and may be able to demonstrate this by resisting conformity, such as holding their ground or acting independently from others' opinions. To deliver the idea, I think it would be good to use male teenagers as the main characters, or at least put male teenager characters in the play so that readers can identify the differences. It would be nice to find other works out there that will explore about it.

\section{REFERENCES}

Agustiani, H. (2006). Psikologi perkembangan pendekatan ekologi kaitannya dengan konsep diri. Bandung: PT Refika Aditama.

Baron, A.R., \& Byrne, D. (2005). Psikologi sosial edisi kesepuluh jilid 2. Jakarta: Erlangga.

Dariyo, A. (2004). Psikologi perkembangan dewasa muda. Bandung: Ghalia Indonesia.

Jones, J. (n.d). The modern theatre: realism Retrieved February 18, 2018, from http://homepage.smc.edu/jones_janie/TA\%202/8Realism.htm

Kelman, H.C. (1958). Compliance, Identification, and Internalization: Three Processes of Attitude Change. The Journal of conflict resolution, 2(1), 51-60.

Mastuti, I. (2008). 50 Kiat percaya diri. Jakarta: Hi-Fest Publishing.

Myers, D.G. (2012). Psikologi sosial. Jakarta: Salemba Humanika.

Oswalt, A. (2010). Teens and peer relationships. Retrieved February 18, 2018, from https://www.mentalhelp.net/articles/teens-and-peer-relationships/

Script. (n.d). Retrieved September 2, 2017, from

http://www.bbc.co.uk/bitesize/standard/english/lit_form/script/revision/1/ 